\title{
Natural Predatory Enemies of Mango Red Mite Oligonychus mangiferus (Tetranychidae) in Eastern Egyptian Mango Orchards
}

\author{
Hamdy Mahmoud El-Sharabasy \\ Plant Protection Dept., Fac. of Agric., Suez Canal Univ., Ismailia, Egypt, helsharabasy@yahoo.com.
}

\begin{abstract}
Survey for natural predatory enemies of the mango red spider mite, Oligonychus mangiferus (Rhaman and Sapra), on mango trees were carried out in Ismailia governorate, Egypt to determine prospective species for the biological control of this pest. One peak of $O$. mangiferus during the year, from April to June was noticed. Total averages of 218.84 specimens of natural predatory enemies were found in 240 collected samples. Of these, 176.57 were predatory mites and 42.27 were predatory insects. Twelve species of predaceous arthropods, including mites and insects, have been reported in association with $O$. mangiferus, of which Typhlodromus pyri Schueten was the most abundant representing $14.06 \%$ of the total collected predaceous mites. Most of collected predatory mites and insects were generalist predators. Orius albidipennis (Reuter) was the most abundant representing $46.49 \%$ of the total collected predatory insects. The distribution patterns of natural enemies always correlated with abundance of the mango red spider mite.
\end{abstract}

Key words: Oligonychus mangiferus, Natural enemies, Biological control.

\section{INTRODUCTION}

Mango, Mangifera indica L. (Anacardiacea) is the most commercially and widely cultivated fruit tree in Ismailia governorate, Eastern Egypt. It is being grown throughout the year and subjected to attack by number of insect and mite pests. Spider mites are important pests of mango trees. Among them, Oligonychus mangiferus that infest leaves of all mango varieties in Egypt (Zaher, 1986). It's widely distributed in many countries, and known to feed on 23 plant families including field and truck crops and ornamentals (Mignon and Flechtmann, 2004). The infestations occurs on the upper leaf surfaces forming damage to leaves that inhibits photosynthesis and increases transpiration and severe infestations can lead to necrosis, shoot dieback and premature leaf fall (Al-Azzazy, 2005).

Biological control has great potential as a tactic for regulating pest populations in integrated pest management programs in mango orchards. Therefore, it is important to survey predators associated with the mango red spider mite in Egypt and its roles as a biocontrol agents in order to minimize use of pesticides. Since there are few studies on $O$. mangiferus and its predators, this study is considered a base for monitoring and controlling this mite pest for establishing IPM strategies in mango orchards in Egypt.

\section{MATERIALS AND METHODS}

A field survey was conducted in 2012 in an area of 15 feddans planted with mixed varieties of mango trees at experimental farm of the faculty of agriculture, Suez Canal University. The mango orchards received normal agricultural practices and no chemical control was applied. One hundred leaves were picked out every two weeks from ten trees at random representing the orchard. The leaves were examined and numbers of $O$. mangiferus eggs, immatures and adults were recorded as well as different predators (insects and mites). Mite species were directly mounted in Hoyer's medium and identified. Acarophagous insects were also recorded. Average temperature and relative humidity, throughout the inspected period were recorded.

\section{RESULTS AND DISCUSSION}

\section{Occurrence and population dynamics of $O$. mangiferus}

A total of 1315 of all stages (687 eggs, 177 immatures and 451 Adults) of mango red spider mite was collected per one hundred leaves during JanuaryDecember 2012 (Fig. 1b). O. mangiferus was observed in low numbers in January, increased gradually from April to reach its peak (182 eggs, 52 immatures and 127 adults / 100 leaves) in June at average temperature $36.5^{\circ} \mathrm{C}$ and relative humidity $84.6 \%$. The population was positively correlated with the prevailing temperatures $(r=0.685,0.716$ and 0.771 for eggs, immatures and adults, respectively). Al-Azzazy (2005) mentioned that the populations of $O$. mangiferus reached the maximum in first of August and in mid October on Alphonso mango cultivar in Cairo region. The population peak maybe formed by mites that migrated from alternative hosts such as deciduous trees onto the mango trees in spring (Zaher, 1986).

\section{Predaceous mites associated with $\boldsymbol{O}$. mangiferus:}

Several predatory mites were observed on mango leaves preying upon the mango red mite $O$. mangiferus. A total average of 176.57 specimens of predatory mites representing 9 species in 5 families were found in 240 collected samples of mango leaves 


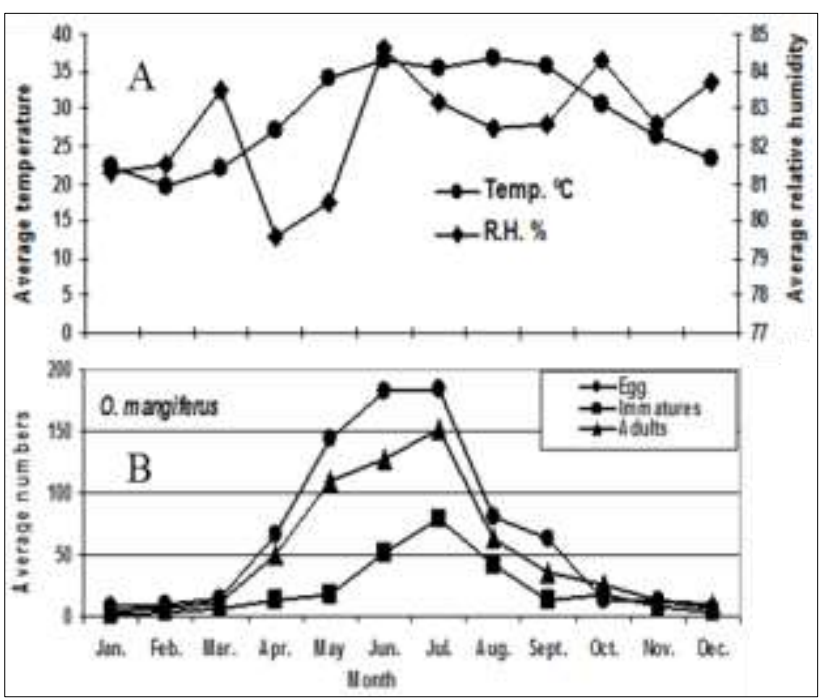

Fig. (1): Population trends of $O$. mangiferus on mango leaves during 2012

in 2012 (Table 1). Five species of the suborder Gamasida and four species of the suborder Actinedida were recorded. All gamasid mites belonged to the family Phytoseiidae. Of which, Amblyseius cucumeris (Oudemans) represented $13.88 \%$ and A. enab El-Badry represented $12.89 \%$ of the total collected predaceous mites. A. cucumeris and A. enab were recorded with about $10 \%$ of collected samples. Euseius scutalis Athias-Henriot, Typhlodromus mangiferus Zaher and El-Badry and T. pyri Schueten were represented by $20.53 \%$, $12.25 \%$ and $14.06 \%$ of the total collected predaceous mites, respectively. Each of them was recorded in about $60 \%$ of collected samples with moderate numbers (Table1).

The distribution pattern of phytoseiid mites always correlated with abundance of the mango red mite. Highly significant correlations $(\mathrm{p}=0.001)$ was observed between A. cucumeris, A. enab, E. scutalis and $T$. pyri and adult stage of $O$. mangiferus ( $r=$ $0.912,0.839,854$ and 0.946 , respectively) as well as temperature $(r=0.725)$ (Table 2). This may indicate that $O$. mangiferus as prey type probably play an important part of the predator's diet. Phytoseiid mites are generalist predators live on plants and in the upper soil layers predating on mites and small insects. Yee et al., (2001) found Euseius hibisci (Chant) associated with Oligonychus perseae Tuttle, Baker and Abbatiello and could consume approximately 5 individuals per day. They also mentioned that, because $E$. hibisci is a specialized pollen feeder, it may not be a significant predator of $O$. perseae. Members of the family Phytoseiidae were known as predators of different stages of spider mites and had a remarkable ability to suppress spider mite populations. This agreed with those given by Kandeel et al., (1986) who reported that phytoseiid mite, T. mangiferus and Amblyseius swirskii A.-H. were most abundant on different fruit trees feeding on $O$. mangiferus.

Zaher (1986) and El-Halawany (2003) recorded the predaceous mites $A$. swirskii and T. mangiferus associated with $O$. mangiferus on mango trees in different localities in Egypt. Momen and AbdelKhalek (2009) collected E. scutalis, Typhlodromips swirskii (Athias-Henriot) and Typhlodromus athiasae Porath from mango orchards in Egypt.

The actinedids included one species of each family of the families Stigmaeidae, Cheyletidae, Cunaxid and Neophyllobiidae. Agistemus exsertus Gonzalis represented $9.03 \%$ of the total collected predaceous mites (moderate numbers). Negative correlation was observed between $A$. exsertus and all stages of $O$. mangiferus as well as temperature (Table 2). Stigmaeids are in their majority predaceous, feeding on the eggs of tetranychids, tenuipalpids and other small arthropods (El-Sharabasy, 2000). El-Halawany (2003) recorded the predaceous mite $A$. exsertus associated with $O$. mangiferus on mango trees in different localities in Egypt. Also, the cheyletid Cheletogenus ornatus (C. \& F.) and the cunaxid Cunaxa setirostris (Hermann) were recorded in few numbers. The neophyllobiida Neophyllobiius mangiferus Zaher and Gomaa was rare as being recorded in one sample only by 2-3 individuals.

Predatory mite species i.e. gamasids and actinedids appeared to be generalist predators of most spider mites and including $O$. mangiferus. Previous laboratory studies confirmed feeding some predaceous mites on the genus Oligonychus (Shih et al., 1993; Hafez et al., 1983and Rahman et al., 2013).

\section{Predaceous insects associated with $O$. mangiferus:}

A total average of 42.27 specimens of acarophagous insects belonging to the families: Chrysopidae, Coccinellidae and Anthocoridae were recorded (Table 1). The family Chrysopidae was represented by one generalist species; Chrysopelea carnea Stephens which its larvae were collected in few numbers, representing $16.98 \%$ of the total collected predatory insects. Larvae of the predator, Coccinella undecimpunctata were recorded in few numbers representing $36.71 \%$. The population of the two predators fluctuated in few numbers and disappeared completely during January and February. This result is in agreement with that obtained by Nangia et al., (1989) who observed that coccinellid numbers started to increase from April and reached its peak during June and July.

Adults and larvae of most coccinellid species (ladybird beetles) are predaceous of other small insects and mites (Fiaboe et al., 2006). The coccinellid species Stethorus sp. was observed in 
Table (1): list of natural enemies of $O$. mangiferus on mango trees in Ismailia governorate in 2012

\begin{tabular}{|c|c|c|c|c|c|c|}
\hline Class & $\begin{array}{l}\text { Sub class / } \\
\text { Order }\end{array}$ & Family & Genus and species & $\begin{array}{c}\text { Average } \\
\text { No./100 leaves }\end{array}$ & $\begin{array}{l}\text { collected } \\
\text { stage }\end{array}$ & $\begin{array}{c}\text { Types and } \\
\text { occurrence }\end{array}$ \\
\hline \multirow{9}{*}{ Arachnida } & \multirow{9}{*}{ Acari } & Phytoseiidae & Amblyseius cucumeris (Oudemans) & 24.51 & $\mathrm{E}, \mathrm{I}$ and $\mathrm{A}$ & generalist ++ \\
\hline & & & A. enab El-Badry & 22.77 & E, I and A & generalist ++ \\
\hline & & & Euseius scutalis Athias-henriot & 36.26 & $\mathrm{E}, \mathrm{I}$ and $\mathrm{A}$ & generalist ++++ \\
\hline & & & T. mangiferus Zaher and El-Badry & 21.63 & E, I and A & generalist ++++ \\
\hline & & & Typhlodromus pyri Schueten & 24.83 & $\mathrm{E}, \mathrm{I}$ and $\mathrm{A}$ & generalist ++++ \\
\hline & & Stigmaeidae & Agistemus exsertus Gonzalis & 15.96 & $\mathrm{I}$ and $\mathrm{A}$ & generalist ++++ \\
\hline & & Cheyletidae & Cheletogenus ornatus (C. and F.) & 11.65 & $\mathrm{~A}$ & generalist ++ \\
\hline & & Cunaxidae & Cunaxa setirostris (Hermann) & 10.23 & A & generalist ++ \\
\hline & & Neophyllobiidae & $\begin{array}{l}\text { Neophyllobiius mangiferus Zaher and } \\
\text { Gomaa }\end{array}$ & 8.73 & $\mathrm{~A}$ & generalist + \\
\hline \multirow{3}{*}{ Insecta } & Neuroptera & Chrysopidae & Chrysoperla carnea Stephens & 7.18 & $\mathrm{~L}$ & generalist ++ \\
\hline & Coleoptera & Coccinellidae & Coccinella undecimpunctata $\mathrm{L}$. & 15.52 & $\mathrm{~L}$ & generalist ++ \\
\hline & Hemiptera & Anthocoridae & Orius albidipennis (Reuter) & 19.57 & $\mathrm{~L}$ and $\mathrm{A}$ & generalist ++++ \\
\hline
\end{tabular}

Table (2): Correlation coefficient between $O$. mangiferus, temperature, relative humidity and natural enemies

\begin{tabular}{|c|c|c|c|c|c|}
\hline \multirow{3}{*}{ Species } & \multicolumn{5}{|c|}{ Correlation coefficient values } \\
\hline & \multicolumn{3}{|c|}{ O. mangiferus } & \multirow[b]{2}{*}{${ }^{\circ} \mathrm{C}$} & \multirow[b]{2}{*}{ R.H.\% } \\
\hline & Eggs & Immatures & Adults & & \\
\hline Amblyseius cucumeris & $0.935^{* * * *}$ & $0.686^{*}$ & $0.912^{* * *}$ & $0.725^{\text {*** }}$ & 0.144 \\
\hline Amblyseius enab & $0.839^{* * * *}$ & $0.629^{*}$ & $0.839^{* * *}$ & $0.816^{* * *}$ & 0.168 \\
\hline Euseius scutalis & $0.873^{* * * *}$ & $0.701^{* *}$ & $0.854^{* * *}$ & $0.792^{* * *}$ & 0.181 \\
\hline Typhlodromus mangiferus & $0.754^{* *}$ & 0.455 & $0.737^{* *}$ & $0.579^{*}$ & -0.000 \\
\hline Typhlodromus pyri & $0.949^{* * *}$ & 0.789 & $0.946^{* * *}$ & $0.698^{*}$ & 0.182 \\
\hline Agistemus exsertus & -0.465 & -0.351 & -0.473 & -0.206 & 0.071 \\
\hline Cheletogenus ornatus & 0.264 & 0.166 & 0.273 & 0.246 & -0.359 \\
\hline Cunaxa setirostris & -0.146 & 0.162 & -0.073 & 0.147 & 0.159 \\
\hline Neophyllobiius mangiferus & 0.366 & $0.850^{* *}$ & $0.796^{* *}$ & $0.527^{*}$ & 0.065 \\
\hline Chrysopelea carnea & 0.133 & -0.266 & 0.120 & 0.167 & -0.787 \\
\hline Coccinella undecimpunctata & 0.427 & -0.090 & 0.374 & 0.210 & -0.397 \\
\hline Orius albidipennis & $0.787^{* *}$ & $0.513^{*}$ & $0.750^{* *}$ & 0.399 & -0.133 \\
\hline
\end{tabular}

$* P \Re 0.05 * * P \Re 0.01 * * * P \Re 0.001$

association with citrus red mite Panonychus citri McGroger as the most abundant natural enemy (Jamieson et al., 2005). Ahmed (1988) found C. carnea and Orius sp. in association and fed on Cenopalpus pulsher (C. \& F.), Tetranychus cinnabarinus Boisd., T. cucurbitacearium and Panonychus ulmi (Koch) on fruit trees. Family Anthocoridae was represented by one predator, Orius albidipennis (Reuter) in moderate numbers, representing $46.49 \%$ of the total collected predatory insects. Significant correlations ( $\square$ 0.01) were observed between this predator and all stages of $O$. mangiferus (Table 2). O. albidipennis is a common predator in various cropping systems, and capable of consuming 30 or more spider mites per day (Sobhy et al., 2010). It increased in numbers shortly after the mite density reached high levels. This increase might caused by translocation within the orchard or immigration from elsewhere. Data showed that, the predator disappeared from the mango orchard in accordance with the rapid decrease of the mite density in December. The most plausible explanation for the predators' disappearance is that mostly predators emigrated from the orchard to other plant hosts (Kitashima and Adachi, 2006). Yee et al., (2001) found Orius sp. And Chrysoperla sp. associated with $O$. perseae on avocado fruits. Among the biotic factors influencing the degree of infestation of different pests are the populations of the natural enemies associated with it in nature. One of the desirable characteristics of natural enemies used for biological control is their ability to locate hosts readily. Predators that discover spider mites have either done so by chance or by some, presumably semiochemical, cues. A second important criterion is that they should be able to complete their life history on the prey (Lentern and Woets, 1988).

This study has identified several species of predacious mites and insects that may play a role in the regulation of populations of the phytophagous mite $O$. mangiferus on mango trees in Ismailia 
governorate, Egypt. The results showed a strong association and synchrony between the collected predators and $O$. mangiferus suggested that they may be important biological control agents. Further studies are needed to: 1- Evaluate the potential of these predators, as biological control agents of O. mangiferus. 2- Know how various acaricides will affect natural enemies populations.

\section{ACKNOWLEDGMENTS}

The author thanks N. Mandour Prof of Entomology, Plant Protection Department, Faculty of Agriculture, Suez Canal University for confirming identification the acarophagous insects.

\section{REFERENCES}

Al-Azzazy, M. M. 2005. Integrated management of mites infesting mango trees. Ph. D. Thesis, Cairo, Egypt, Al-Azhar University, 120 pp.

Ahmed, S. A. 1988. Studies on the biological control of two spotted spider mites in Suez Canal area. Thesis, Ph. D. Fac. of Agric. Ismailia, Egypt, $121 \mathrm{pp}$.

El-Halawany, M. 2003. Mites associated with mango trees in Egypt. Eighth Arab Congress of Plant Protection, El-Beida, Libya.

El-Sharabasy, H. M. 2000. Ecological Studies on phytophagous and predaceous mites at newly reclaimed lands in Ismaila Governorate. M.Sc. Thesis, Faculty of Agriculture, Suez Canal University, $110 \mathrm{pp}$.

Fiaboe, K. K. M.; Fonseca, R. L.; Moraes, G. J. de, Ogol, C. K. P. O. and Knapp, M. 2006. Identification of priority areas in South America for exploration of natural enemies for classical biological control of Tetranychus evansi (Acari: Tetranychidae) in Africa. Biological Control, 38:373 - 379 .

Hafez, S. M.; Rasmy, A. H. and El-Sawy S. A. 1983. Effect of prey species and stages on predatory efficiency and development of the stigmaeid mite, Agistemus exsertus. Acarologia, 24: 281-283.

Jamieson, L. E.; Charles, J. G.; Stevens, P. S.; McKenna, C. E. and Bawden, R. 2005. Natural enemies of citrus red mite (Panonychus citri) in citrus orchards. New Zealand Plant Protection, 58:299-305.

Kandeel, M. F.; Afifi, A. M. and Nawar, M. S. 1986. Mites inhabiting plants and soil in Sinai newly reclaimed lands. Bull. Soc. Ent., Egypt,
66:211-225.

Kishimoto, H. and Adachi, I. 2006. Effects of predacious insects on the population dynamics of three spider mite species (Acari: Tetranychidae) on Japanese pear. J. Acarol. Soc. Jpn., 15(1): 4754.

Lenteren, J. C. and Woets, J. 1988. Biological and integrated pest control in greenhouses. Annual Review of Entomology, 33: 239-269.

Mignon, A. and Flechtmann, C. H. W. 2004. First addition and correction to the world catalogue of the mite family (Acari: Tetranychidae). Intern. J. Acarol., 30:143-152.

Mohamed, O. M. O. and Nabil, H. A. 2014. Survey and biological studies on mite species and scale insects inhabiting mango trees at Sharkia Governorate, Egypt. Journal of Entomology, 11: 210-217.

Momen, F. M. and Abdel-Khalek, A. 2009. Cannibalism and intraguild predation in the phytoseiid mites Typhlodrompis swirskii, Euseius scutalis and Typhlodromus athiasae (Acari: Phytoseiidae). Acarina, 17 (2): 223-229.

Nangia, N.; Jagadish, P. S. and Nageshchandra, B. K. 1989. Biology and control of Oligonychus mangiferus (Acari: Tetranychidae) on Terminalia spp., important host plants of silkworms. Mysore J Agric Sci., 23:355-358.

Rahman, V. J.; Babu, A.; Roobakkumar, A. and Perumalsamy, K. 2013. Life table and predation of Neoseiulus longispinosus (Acari: Phytoseiidae) on Oligonychus coffeae (Acari:Tetranychidae) infesting tea. Exp. \& Appl. Acarol., 60:229-240.

Shih, C. I.; Chang, H. Y.; Hsu, P. H. and Hwang, Y. F. 1993. Responses of Amblyseius ovalis (Evans) (Acarina: Phytoseiidae) to natural food resources and two artificial diets. Exp. \& Appl. Acarol., 17: 503-519.

Sobhy, I. S.; Sarhan, A. A.; Shoukry, A. A.; El-Kady, G. A.; Mandour, N.S. and Reitz, S. R. 2010. Development, consumption rates and reproductive biology of Orius albidipennis reared on various prey. BioControl, 55:753-765.

Yee, W. L.; Philips, P. A.; Rodgers, J. L. and Faber, B. A. 2001. Phenology of arthropod pests and associated natural predators on avocado leaves, fruit, and in leaf litter in Southern California. Environ. Entomol., 30(5):892-898.

Zaher, M. A. 1986. Survey and ecological studies of phytophagous, predaceous and soil mites in Egypt. Final report PL 480, Programme USA Project No. EG. ARS-30, grant No. FG-139. 